\title{
Obituary
}

\section{Klaus Bergmann, MD, FRCPsych}

Formerly Consultant Old Age Psychiatrist at the Bethlem Royal and Maudsley Joint Hospital, London, UK

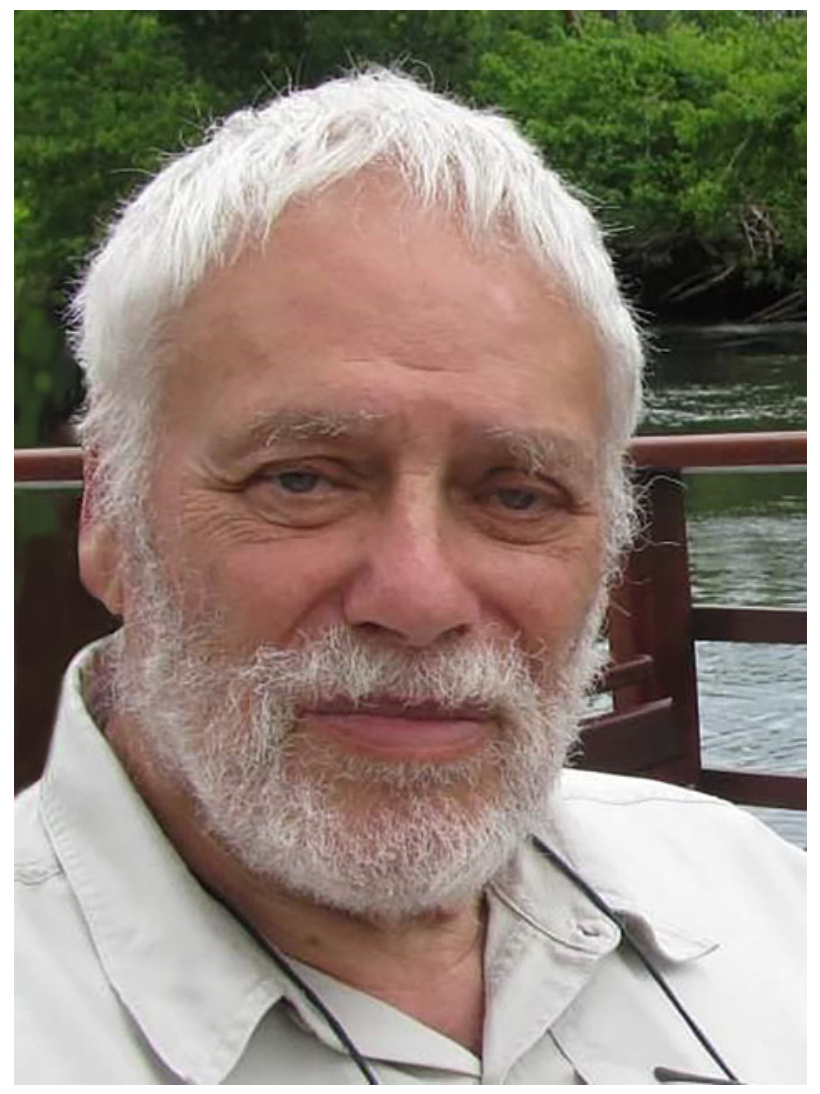

Klaus Bergmann, who died following a stroke on 5 December 2020, was one of the towering figures in British old age psychiatry in its early years, playing a major role in bringing the specialty to maturity. In the 1960s and 1970s, he was based in the Department of Psychiatry at Newcastle University, headed by Martin Roth. Mentored by David Kay and in collaboration with Gary Blessed and Bernard Tomlinson, Klaus was deeply involved in one of the first community cohort studies of the prevalence and outcomes of old age mental disorders outside hospitals. The important findings of these studies have dictated policy ever since., ${ }^{1,2}$

Although involved in research, Klaus was a superb clinician who cared more about his patients than he did about anything else at his work. His acumen in diagnosis and treatment was second to none. He was the reason many of his trainees went into old age psychiatry, some of those now occupying the highest levels in the profession.

He was born in 1930 in Dresden, younger brother to two older sisters, to Fritz and Alice Bergmann. Fritz owned a millinery firm that he was able to re-establish in Luton after emigration from Germany. In 1937, before the Second World War, his Jewish family moved via Palestine to England. He would often recount his childhood disappointment that he had not been allowed to wear the uniform and carry the dagger of the Hitler Youth, which he coveted.

Klaus was educated first at St George's School, Harpenden, following which he studied medicine at Sheffield University, where he met his wife Marie, a fellow student reading German. After National Service, he returned to Sheffield for psychiatric training under Erwin Stengel, also a refugee from the Nazis. This gave him a broad outlook based both on rigorous history-taking and mental state examination, but with psychoanalytic insights. He always maintained an affectionate respect for Stengel but, as was the case with others among his senior colleagues, he could never resist telling humorous stories about them. This characteristic betrayed both immense respect for those Klaus deemed worthy, combined with a refusal to adopt blinkered hero worship.

In 1964, Klaus moved from Sheffield to Newcastle, where the Department of Psychiatry was headed by Martin Roth, and it was here that he entered old age psychiatry. Klaus often said that he regarded Roth as the Kraepelin of old age psychiatry, i.e. a founding father in terms of classification and phenomenology. Once again, Klaus enjoyed poking fun at him without ever losing respect for his important contributions to the specialty. In 1966, Klaus took up a consultant post at St Francis Hospital, Haywards Heath, Sussex, where he was overworked and grossly under-resourced. So, in 1969, he returned to Newcastle, continuing to carry out research in the community.

At heart, Klaus was a clinician and a teacher and, in 1979, at the invitation of Raymond Levy, he moved down to London to the Bethlem Royal and Maudsley Hospital as a consultant old age psychiatrist, replacing Felix Post, who had retired. With typically wry humour he asked Raymond: 'Do you think they'll mind that I'm not a gentleman?'. As a matter of fact, they did not mind, and he settled in there very well. At the Maudsley he worked alongside Raymond Levy, who became Professor of Old Age Psychiatry. Later, they were joined by Robin Jacoby and Marisa Silverman (now Parrish).

Klaus inspired loyalty through his clinical skills and his courage. He was not frightened to offend people in defence of his patients. For example, if he saw something that he regarded as shocking, he would, himself, shock the perpetrator. One day, he arrived at a care home to be led into the day-room, where all the residents were sitting round the walls except for one old lady who was on a commode in the middle of the room, incompletely shielded by one or two movable screens. Klaus turned to the care-home manager and said: 'Oh, do you sh ${ }^{\star \star}$ in your sitting-room?'.

He was often incredibly funny. Never completely shaking off his adolescent schoolboy personality, he was a fount of good and very non-PC jokes, designed on occasions to shock some of the more prudish people at the Maudsley. His office was a chaotic mess, with journals and committee papers all over the desk and the floor. His colleagues used to joke that he would not be able to retire but would have to be removed as a hoarder under a section of the Public Health Act. This delighted him, and he often boasted about it. In the end, he retired without recourse to the Public Health Act. Early on in his retirement he wrote reports for the General Nursing Council in connection with disciplinary action. He was rather fond of what he called his 'naughty nurses'. 
Klaus enjoyed a long and happy marriage to Marie, who survives him with their son George, their daughter Caroline, and three grandchildren. Vicky, their elder daughter, died of cancer in 2014.

\section{References}

1 Kay DWK, Bergmann K. Physical disability and mental health in old age. J Psychosom Res 1966; 10: 3-12.

2 Kay D, Bergmann K, Foster E, McKechnie A, Roth M. Mental illness and hospital usage in the elderly: a random sample followed up. Compr Psychiatry 1970; 11: 26-35.

Robin Jacoby and Robert Howard

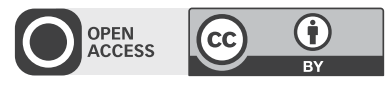

(C) The Authors 2021. Published by Cambridge University Press on behalf of the Royal College of Psychiatrists. This is an Open Access article, distributed under the terms of the Creative Commons Attribution licence (http://creativecommons.org/licenses/by/4.0/), which permits unrestricted re-use, distribution, and reproduction in any medium, provided the original work is properly cited.

\section{W. Alwyn Lishman, MD, FRCP, FRCPsych (Hon)}

Emeritus Professor of Neuropsychiatry, Institute of Psychiatry, Psychology and Neuroscience, King's College, London, UK

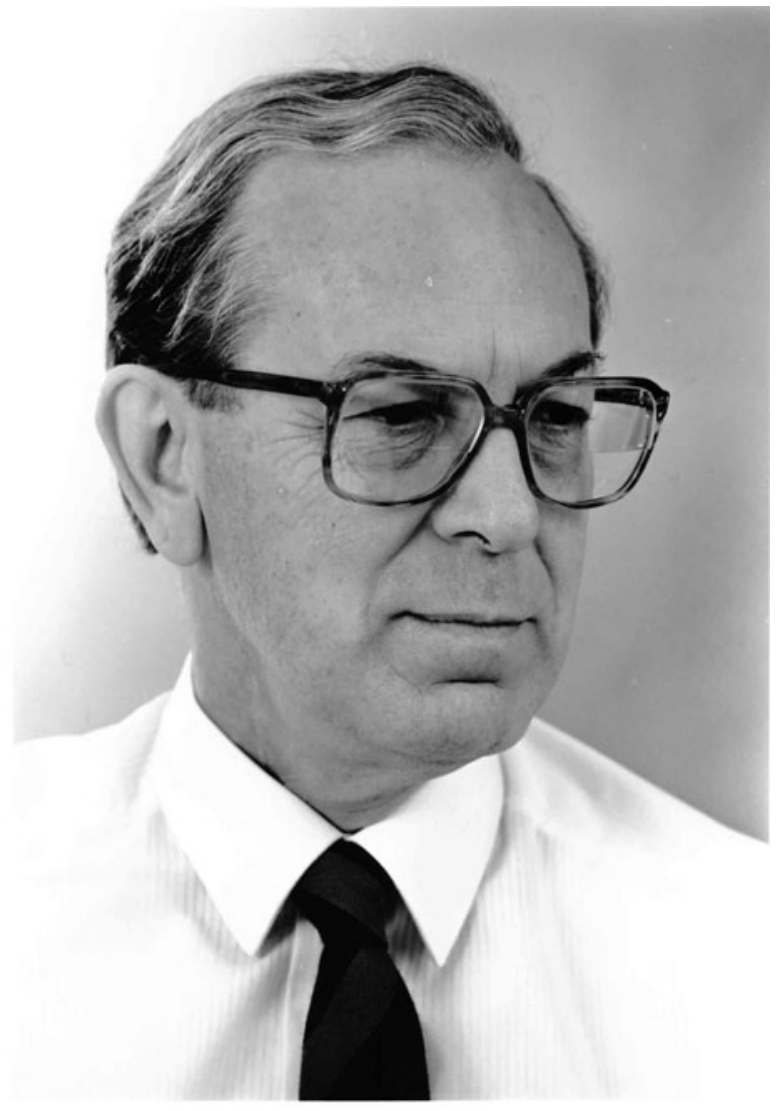

Alwyn Lishman, who died on 24 January 2021, aged 89, was the first Professor of Neuropsychiatry to be appointed in the UK. He was the co-founder and Honorary Life President of the British Neuropsychiatry Association (BNPA). In 2016, when addressing the BNPA, Alwyn said that he wanted to be remembered for what he did, in terms 'expressed concisely', thus setting a challenge for those of us who now wish to celebrate his exceptional contribution to psychiatry. His famous book Organic Psychiatry: The Psychological Consequences of Cerebral Disorder, ${ }^{1}$ first published in 1978, set an example of conciseness and clarity in medical writing while at the same time single-handedly defining the discipline of neuropsychiatry. Alwyn considered this book to be his most important legacy; two further single author editions followed in 1987 and 1997. At the time this book was published, neuropsychiatry was a small specialist interest. Now, thanks considerably to his influence, it is a major component of psychiatric research and practice.

Alwyn saw neuropsychiatry as much more than an admixture of neurology and psychiatry, as involving the understanding of brain mechanisms in relation to mental disorder, and benefiting from advances in neuropsychology, biochemistry, genetics, imaging and many other disciplines. For him, neuropsychiatry could equally apply to the study of schizophrenia, affective disorders or traumatic brain injury, in fact to the whole of psychiatry. By defining neuropsychiatry in this way, he was redressing the balance between brain and mind that had been polarised by the influence of psychoanalytic theory. ${ }^{2}$

His research was wide-ranging. Memory was one of his early interests. In what he called 'a crude approximation to testing Freud's theory of repression', he explored the effect of the hedonic tone of the material to be remembered, finding that, while normal people recalled pleasant material better, the pattern was reversed in depressed patients. Later his emphasis was to exploit brain imaging in relation to psychiatry, and studies of brain damage in alcoholism and psychosis of epilepsy followed.

Alwyn Lishman was born in Houghton-le-Spring, County Durham, on the 16 May 1931. His father, George Lishman, had been a prisoner during the First World War and, when his poor health prevented him from becoming a doctor, he ran the family business, a tallow chandlery that supplied candles for mining and shipbuilding. His mother Madge (née Young) was a teacher, described by Lishman as something of a dragon who locked him up with his sister Valerie until they finished their homework without any mistakes. Alwyn's innate perseverance and attention to detail must have been greatly enhanced by this strict upbringing.

For somebody who was a master of words it is perhaps surprising to know that he could read music before he could read words. He assiduously played the piano from the age of 5 and wanted to be a musician but pressure from his father finally persuaded him to go to Birmingham University to study medicine. His interest in the relationship between brain and behaviour was sparked by his time working with Solly Zuckerman while doing an intercalated degree in Anatomy and Physiology. He qualified in 1956.

After his house jobs, he spent his National Service practising neurology. He was posted to the Army head injury hospital outside Oxford, where he was mentored by Ritchie 